\title{
THE EFFECT OF MADRASAH HEAD LEADERSHIP, ACADEMIC SUPERVISION AND FUNCTIONAL TRAINING ON TEACHER PERFORMANCE ALIYAH MADRASAH INTHE DISTRICT OF BARRU
}

\author{
H. Abd. Gani ${ }^{1}$, Basri Modding 2 , Andi Bunyamin ${ }^{3}$, Akhmad Syahid ${ }^{4}$ \\ Universitas Muslim Indonesia ${ }^{1}$ \\ Email: hindiabdulgani@gmail.com², basri.modding@umi.ac.id², \\ andi.bunyamin@umi.ac.id³ ${ }^{3}$ ahkmadsyahid@umi.ac.id ${ }^{4}$
}

\begin{abstract}
Abstrak. Penelitian ini dilaksanakan dengan bertujuan untuk; (1) menguji dan menganalisis pengaruh kepemimpinan kepala Madrasah, supervisi akademik, dan diklat fungsional terhadap kinerja guru Madrasah Aliyah, (2) menguji dan menganalisis pengaruh kepemimpinan kepala Madrasah terhadap kinerja guru Mardasar Aliyah, (3) menguji dan menganalisis pengaruh supervisi kepala Madrasah terhadap kinerja guru Mardasar Aliyah, (4) menguji dan menganalisis pengaruh diklat fungsional terhadap kinerja guru Mardasar Aliyah di Kabupaten Barru, dan Penelitian ini menggunakan data primer dan data skunder, data primer melalui survei pada Madrasah Aliyah di Kabupaten Barru yang dilaksanakan mulai bulan September sampai dengan bulan November 2020 jumlah populasi 273 orang guru dari 12 Madrasah Aliyah. Penetapan sampel menggunakan rumus slovin, yaitu 12 Madrasah Aliyah dan terpilih 162 orang responden data skunder meliputi data dokumen yang ada di Madrasah hasil penilaian kinerja guru yang dilaksanakan oleh kepala Madrasah setiap tahun. Analisis data yang digunakan adalah deskriptif untuk menjelaskan dan deskripsikan data penelitian, sedangkan analisis data kuantitatif menggunakan alat analisis Regresi Linier Berganda dengan program SPSS. Hasil penelitian ini terdapat nilai (R2/rsquare) sebesar 0,976 Artinya 97,6 persen variabel bebas kepemimpinan kepala madrasa, supervisi akademik, dan diklat fungsional secara simultan mempengaruhi variabel dependen hasil kinerja guru madrasah aliyah dan selebihnya sekitar 2,4\% mempengaruhi variabel lain yang tidak termasuk dalam penelitian ini. dan Secara vartial, bahwa kepemimpinan kepala madrasah berpengaruh positif dan signifikan terhadap kinerja guru madrasah aliyah di Kabupaten Barru sebesar 96,9 persen, sedang 13,1 persen lainnya dapat dijelaskan oleh faktor-faktor lain yang tidak diteliti dalam penelitian ini, dan supervisi akademik berpengaruh positif dan signifikan terhadap Kinerja guru pada madrasah aliyah di Kabupaten Barru. sebesar 89,1 persen, sedang 10,9 persen lainnya dapat dijelaskan oleh faktor-faktor lain, serta, diklat fungsional mempunyai pengaruh yang signifikan terhadap kinerja guru madrasah aliyah di Kabupaten Barru sebesar 72,1 persen, sedang 27,9 persen lainnya dapat dijelaskan oleh faktor-faktor lain, dan selanjutnya kepemimpinan kepala madrasah aliyah negeri, dan pelaksanaan supervisi akademik. serta diklat fungsional lebih baik dari pada madrasah aliyah swasta di Kabupaten Barru
\end{abstract}

\section{Kata kunci: Kepemimpinan Kepala Madrasah, Supervisi Akademik, Diklat Fungsional Kinerja Guru.}

\begin{abstract}
This research was conducted with the aim to; (1) examine and analyze the influence of Madrasah head leadership, academic supervision, and functional training on the performance of Madrasah Aliyah teachers (2) examine and analyze the influence of Madrasah head leadership on the performance of Madrasa Aliyah teachers (3) examine and analyze the effect of Madrasah head supervision on the performance of Mardasar Aliyah teachers (4) examine and analyze the effect of functional training on the performance of Madrasah Aliyah teachers in kabupaten Barru, and This research uses primary data and secondary data, primary data through a survey on Madrasah Aliyah in kabupaten Barru which was conducted from September to November 2020 with a population of 273 teachers from 12 Madrasah Aliyah. Determination of the sample using the slovin formula, which is 12 Madrasah Aliyah and 162 respondents were selected. Secondary data includes document data in Madrasah resulting from teacher performance assessments conducted by the head of Madrasah each year. The data analysis used is descriptive to explain and describe the research data, while the quantitative data analysis uses Multiple Linear Regression analysis tool with SPSS program. The results of this research, there are value (R2/r-square) of 0.976. Means that 97.6 percent of the independent variables are madrasah principal leadership, academic supervision, and functional training simultaneously affect the dependent variable on the performance of madrasah aliyah teachers and the rest is about $2.4 \%$ affect the other variables that are not included in this research. And variably, the leadership of the madrasah principal has a positive and significant effect on the performance of
\end{abstract}


madrasah aliyah teachers in Barru by 96.9 percent, while the other 13.1 percent can be explained by other factors not examined in this research, and academic supervision has an effect positive and significant impact on teacher performance at madrasah aliyah in Barru. by 89.1 percent, while the other 10.9 percent can be explained by other factors, as well as, functional training has a significant effect on the performance of madrasah aliyah teachers in Barru by 72.1 percent, while the other 27.9 percent can be explained by other factors, and subsequently the leadership of the head of the state madrasah aliyah, and the implementation of academic supervision and functional training is better than private madrasah aliyah in Barru.

\section{Keywords: Madrasah Principal Leadership, Academic Supervision, Teacher Performance Functional Training}

\section{A. Pendahuluan}

Dalam perjalanannya yang panjang dalam waktu yang cukup lama, Undang-Undang No. 2 Tahun 1989 tentang Sistem Pendidikan Nasional dirasa perlu untuk melakukan penyesuaian dan disempurnakan dengan Undang-Undang Dasar Republik Indonesia Tahun 1945, maka disahkanlah Undang-Undang Republik Indonesia No. 20 Tahun 2003 tentang Sistem Pendidikan Nasional. Kehadiran Undang-Undang tersebut sebagai wadah terintegrasinya pendidkan Islam dalam sistem pendidikan nasional, maka pengembangan pendidikan Islam mendapatkan peluang yang sama dengan pendidikan umum. Peran seorang pemimpin dalam menciptakan iklim yang kondusif dalam menjalankan dan menempuh berbagai strategi demi memajukan lembaga pendidikan Islam sangatlah urgen. Karena keberadaan seorang manajer adalah untuk mengatasi berbagai problem kompleks yang dihadapi lembaga pendidikan Islam. Berdasarkan hasil observasi Madrasah Aliyah di Kabupaten Barru pada bulan Februari 2020, terlihat bahwa peneliti mengambil kesimpulan bahwa dari jumlah guru Madrasah Aliyah 273 guru Madrasah Aliyah Kabupaten Barru dari jumlah 273 guru Madrasah terdapat 45\% sebagai guru PNS dan 55\% guru non PNS, data yang lain memberikan informasi bahwa nilai kinerja guru Madrasah Aliyah di Kabupaten Barru berdasarkan hasil observasi awal terdapat 5,49\% nilai kinerja termasuk dalam kategori amat baik, 80,22\% guru mempunyai nilai kinerja dalam kategori baik, dan 14,29\% guru Madrasah Aliyah yang termasuk nilai kinerja dalam kategori cukup. Berdasarkan uraian yang telah dikemukakan di atas, maka dirumuskan masalahmasalah yang diselidiki dalam penelitian ini sebagai berikut: (1) apakah kepemimpinan kepala Madrasah, supervisi akademik, diklat funsional guru berpengaruh positif dan signifikan secara bersama- sama terhadap kinerja guru Madrasah Aliyah di Kabupaten Barru? (2) apakah kepemimpinan kepala Madrasah berpengaruh positif dan signifikan terhadap kinerja guru Madrasah Aliyah Kabupaten Barru? (3) apakah supervisi akademik berpengaruh positif dan signifikan terhadap kinerja guru Madrasah Aliyah Kabupaten Barru? (4) apakah diklat fungsional berpengaruh positif dan signifikan terhadap kinerja guru Madrasah Aliyah Kabupaten Barru? Pada dasarnya penelitian ini bertujuan untuk menemukan jawaban atas masalah-masalah yang telah dirumuskan. Jawaban yang diperoleh diharapkan menjadi bahan masukan yang dapat dijadikan sebagai pedoman dalam menentukan faktor-faktor yang dapat diperbaiki dalam upaya meningkatkan kinerja guru Madrasah Aliya di Kabupatenn Barru: (1) Untuk mengkaji pen garuh kepemimpinan Kepala Madrasah terhadap kinerja guru Madrasah Aliyah di Kabupaten Barru, (2) Untuk mengkaji pengaruh Supervisi Akademik terhadap kinerja guru Madrasah Aliyah di Kabupaten Barru, (3) Untuk mengkaji pengaruh Diklat fungsional terhadap kinerja guru Madrasah Aliyah di Kabupaten Barru, (4) Untuk mengkaji berapa besar kinerja guru Madrasah Aliyah di Kabupaten Barru, (5) Untuk mengkaji pengaruh Kepemimpinan Kepala Madrasah, Supervisi Akademik; dan Diklat fungsional secara bersamasama terhadap kinerja guru Madrasah Aliyah di Kabupaten Barru, penelitian manfaat yang diarapkan adalah sebagai berikut: (1) Sebagai informasi tentang pengaruh kepemimpinan kepala Madrasah Aliyah di Kabupaten Barru, (2) Sebagai informasi tentang kepemimpinan, supervisi akademik, dan diklat fungsional, guru Madrasah Aliyah di Kabupaten Barru, serta 
besarnya variansi kinerja guru Madrasah Aliyah yang dapat ditentukan oleh variabel-variabel kepemimpinan, supervisi akademik dan diklat fungsional. Hal ini dapat menjadi masukan bagi Kemeterian Pendidikan Agama, Depdikdud dan Pemerintah Provinsi Sulawesi Selatan Khususnya Kementerian Pendidikan Agama Provinsi Sulawesi Selatan, (3) Bermanfaat bagi guru sebagai bahan penilaian diri tentang keberadaannya untuk menjadi guru yang profesional dalam rangka melaksanakan tugas dan tanggung jawab sebagai guru Madrasah Aliyah di Kabupaten Barru, (4) Bermanfaat bagi kepala Madrasah sebagai pertimbangan untuk menentukan skala prioritas bahan pembinaan dan peningkatan kinerja guru Madrasah Aliyah, (5) Bermanfaat bagi pembina pendidikan di Madrasah Aliyah sebagai bahan penentu dalam pengambilan kebijakan untuk dapat menata atau membenahi unsur-unsur yang terkait dalam peningkatan mutu pendidikan khususnya Madrasah Aliyah di Kabupaten Barru melalui gaya kepemimpinan kepala Madrasah Aliyah, supervisi akademik dan diklat fungsional guru dalam melaksanakan tugas dengan baik. Kepemimpinan kepala Madrasah adalah kemampuan seorang tenaga fungsional guru yang diberi tugas untuk memimpin suatu Madrasah untuk menggerakkan segala sumber yang pada suatu Madrasah sehingga dapat didayagunakan secara maksimal untuk mencapai tujuan yang telah ditetapkan.

Pemimpin memiliki peran yang penting dalam kehidupan manusia, baik sebagai individu, dalam lingkungan keluarga, masyarakat maupun dalam kehidupan bernegara (Saefullah, 2012: 57). Adapun peran penting pemimpin adalah sebagai berikut: (1) Pelaku utama yang memberikan contoh dalam melaksanakan berbagai tugas atau program yang telah direncanakan dan disepakati bersama, (2) Berperan sebagai representasi dari semua bawahannya.

Kompetensi Kepala Madrasah Peraturan Menteri Pendidikan Nasional Republik Indonesia Nomor 13 Tahun 2007 tentang Standar Kepala Madrasah menetapkan bahwa kepala Madrasah harus memiliki: (1) kompetensi kepribadian, (2) kompetensi manajerial, (3) kompetensi kewirausahaan, (4) kompetensi supervisi dan (5) kompetensi sosial. Peraturan Menteri Agama (PMA) Nomor 58 Tahun 2017) tentang Kepala Madrasah ditetapkan sebagai pengganti peraturan sebelumnya yakni PMA Nomor 29 Tahun 2014. Dalam peraturan tentang kepala madrasah yang terbaru ini tentunya terdapat beberapa penambahan poin dan perubahanperubahan atas peraturan sebelumnya. Penambahan dan perubahan tersebut didasarkan pada regulasi-regulasi yang berlaku maupun kondisi madrasah terkini. Perautuan Meteri Agama Republik ndonesia Nomor 58 Thun 2017, Kepala Madrasah terdiri atas 3 jenis yaitu: (i) Kepala Madrasah PNS pada madrasah yang diselenggarakan pemerintah (madrasah negeri), (ii) Kepala Madrasah PNS pada madrasah yang diselenggarakan masyarakat (madrasah swasta), (iii) Kepala Madrasah Bukan PNS pada madrasah yang diselenggarakan masyarakat (madrasah swasta)

Pengertian supervisi akademik adalah serangkaian kegiatan membantu guru mengembangkan kemampuannya mengelola proses pembelajaran untuk mencapai tujuan pembelajaran (Daresh, 1989, Glickman, et al; 2007:83) supervisi akademik tidak terlepas dari penilaian kinerja guru dalam mengelola pembelajaran. Supervisi akademik merupakan salah satu program kerja kepala Madrasah yang dilaksanakan setiap semester mulai dari: (1) Perencanaan (2) Pelaksanaan supervisi, (3) Tindak Lanjut hasil supervisi Akademik.

Bernadin (dalam Gomes, 2000: 98) menyatakan bahwa diklat fungsional bertujuan untuk memperbaiki performence pada suatu pekerjaan atau ada kaitannya dengan pekerjaan tertentu yang menjadi tangung jawabnya. Husnan (2006: 89) menyatakan bahwa diklat adalah suatu kegiatan untuk memperbaiki kemampuan kerja seseorang. Diklat bertujuan untuk membantu karyawan dalam memahami suatu pengetahuan praktis dan penerapannya, guna meningkatkan keterampilan, kecakapan, dan sikap yang dipelukan organisasi dalam usaha mencapai tujuan. Sejalan dengan hal tersebut (Mandra, 2005:79) menyatakan bahwa diklat adalah suatu usaha sadar, berencana dan sistematis untuk mengubah pengetahuan, sikap, dan keterampilan yang dibutuhkan oleh masyarakat tempat suatu diklat dilaksanakan. 
Kinerja adalah hasil atau taraf kesuksesan yang dicapai seseorang dalam bidang pekerjaannya menurut kriteria tertentu dievaluasi oleh orang - orang tertentu terutama atasan pegawai yang bersangkutan. Kinerja guru adalah kemampuan dan usaha guru untuk melaksanakan tugas pembelajaran sebaik-baiknya dalam perencanaan progran pengajaran, pelaksanaan kegiatan pembelajaran dan evaluasi hasil pembelajaran. Kinerja guru yang dicapai harus berdasakan standar kemampuan profesional selama melaksanakan. Kinerja atau kemampuan guru dalam manajemen pembelajaran paling tidak meliputi: (a) kemampuan dalam menyusun program pembelajaran, (b) kemampuan dalam melaksanakan prosedur pembelajaran, dan (c) kemampuan dalam melaksanakan hubungan antar pribadi dengan peserta didik (Usman, 2004: 119).

\section{B. Metode Penelitian}

Penelitian ini merupakan penelitian dengan pendekatan deskriptif dan inferensial yang bersifat Survai dan Expost facto dengan pendekatan kuantitatif dalam menjawab permasalahan yang diajukan dan menguji keterkaitan antara variabel bebas (variabel independent) dengan variabel terikat (variabel dependent). Survai adalah dibatasi pada penelitian yang datanya dikumpulkan dari sampel atas populasi untuk mewakili seluruh populasi, penelitian Expost facto adalah suatu penelitian yang dilakukan untuk meneliti peristiwa yang telah terjadi dan kemudian melihat kebelakang untuk mengetahui faktor-faktor yang dapat menimbulkan kejadian tersebut, deskriptif adalah mendiskripsikan informasi dalam bentuk yang paling tepat, dapat digunakan dan dimengerti, dan inferensial adalah mengungkap misteri populasi berdasarkan fakta sampel. Sampel merupakan bagian dari jumlah dan karakteristik yang dimiliki oleh populasi (Sugiono, 2015: 118). Karena itu, penelitian ini dilakukan dengan menggunakan sampel yang ditetapkan dengan metode probability sampling, yaitu semua anggota populasi dijadikan sampel penelitian. Karena keterbatasan kemampuan dan waktu dalam pelaksanaan penelitian, maka peneliti menggunakan teknik simple random sampling dalam menetapkan jumlah sampel, tanpa memperhatikan strata yang ada dalam populasi (Sugiono, 2015: 120). Untuk menentukan jumlah sampel, peneliti menggunakan rumus Slovin sebagai berikut:

Berdasarkan rumus Slovin diperoleh jumlah sampel minimal sebesar 162, sehingga jumlah sampel yang diambil sebanyak 162 orang, untuk mengantisipasi pada saat pengumpulan data terdapat responden yang tidak hadir atau sakit.

Teknik yang digunakan untuk menganalisis data penelitian terdiri dari dua macam. Setelah data terkumpul dari hasil kuesioner selanjutnya data diolah untuk memperoleh data skor, kemudian dianalisis dengan menggunkan dua macam teknik, yaitu: (1) analisis statistik deskriptif, (2) analisis statistik inferensial.

Analisis deskriptif digunakan untuk memperoleh gambaran umum mengenai data yang sedang diukur yang disajikan dalam bentuk tabel distribusi frekuensi dan Histogram, teknik analisis yang sering digunakan untuk mendeskripsikan data, antara lain: (a) Ukuran pemusatan data (rata-rata, median, dan modus), (b) Ukuran penyebaran data (rentang, simpangan baku, dan varian)

Berdasarkan judul penelitian ini, maka ada empat variabel yang akan diteliti, yaitu masing-masing kepemimpinan kepala Madrasah , supervisi akademik, dan diklat fungsional guru sebagai variabel bebas (independent) yang diberi syimbol masing-masing $\mathrm{X}_{1}, \mathrm{X}_{2}, \mathrm{X}_{3}$. Sedangkan kinerja guru merupakan variabel terikat (dependent) yang diberi simbol Y. 


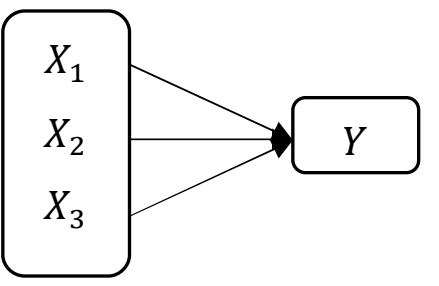

$$
\begin{aligned}
\text { Dengan } \mathbf{x}_{1} & =\text { Kepemi,mpinan Kepala madrasah } \\
\mathbf{x}_{2} & =\text { Supervisi Akademi } \\
\mathbf{x}_{3} & =\text { Diklat Fungsional } \\
\mathrm{Y} & =\text { Kinerja Guru }
\end{aligned}
$$

a. Hipotesis Statistik.

1) Hioptesis I: Pengaruh Kepemimpinan Kepala Madrasah, supervisi akademik, dan Diklat Fungsional guru

Jika diterima maka terbukti secara statistik bahwa $X 1, X 2, X 3$ berpengaruh signifikan terhadap kinerja guru. Model matematis regresi berganda untuk analisis data penelitian ini dirumuskan sebagai berikut:

$Y=\beta_{0}+\beta_{1} X_{1}+\beta_{2} X_{2}+\beta_{3} X_{3}$

2) Hipotesis II: Pengaruh Kepemimpinan Kepala Madrasah

$H_{0} \rightarrow \beta 1=0, H_{1} \rightarrow \beta 1 \neq 0$

Jika H1 diterima maka terbukti secara statistik bahwa $X 1$ berpengaruh signifikan terhadap kinerja guru.

3) Hipotesis III: Pengaruh Supervisi Akademik terhadap Kinerja Guru

$H_{0} \rightarrow \beta 2=0, H_{1} \rightarrow \beta 2 \neq 0$

Jika H1 diterima maka terbukti secara statistik bahwa $X 2$ berpengaruh signifikan terhadap kinerja guru.

4) Hipotesis IV: Pengaruh Diklat Fungsional Guru Terhadap Kinerja Guru.

$H_{0} \rightarrow \beta_{3}=0, H_{1} \rightarrow \beta_{3} \neq 0$

Jika H1 diterima maka terbukti secara statistik bahwa $X_{3}$ berpengaruh signifikan terhadap kinerja guru.

\section{Hasil Penelitian dan Pembahasan}

Berdasarkan hasil SPSS yang digunakan untuk menguji hipotesis penelitian yang berbunyi "kepemimpinan kepala Madrasah Aliyah mempunyai pengaruh yang signifikan terhadap kinerja guru Madrasah Aliyah di Kabupaten Barru". Untuk menguji hipotesis penelitin dilakukan analisis regresi. Data yang digunakan yaitu skor varibel kepemimpinan (X1), dan skor kinerja guru (Y). Analisis regresi dilakukan dengan memakai X sebagai variabel bebas dan $\mathrm{Y}$ sebagai variabel tak bebas.

Analisis regresi linear sederhana dengan uji-F dengan taraf signifikan 0,05 maka hasil statiatik uji-F (nilai $\mathrm{p}=0,000$ ) menunjukkan $\mathrm{H} 0$ ditolak atau $\mathrm{H} 1$ diterima. Ini berarti bahwa varibel X1 mempunyai pengaruh yang signifikan dengan variabel tak bebas Y.

Besarnya sumbangan variabel kepemimpinan terhadap kinerja guru Madrasah Aliyah di Kabupaten Barru ditunjukkan oleh koefisien determinasi (r2) sebesar 0,969 atau 96,9, persen. Artinya, varinsi perubahan variabel kinerja guru Madrasah Aliyah dapat dijelaskan oleh variabel Kepemimpinan Kepala Madrasa Aliyah sebesar 96,9 persen, sedang 3,1 persen lainnya dapat dijelaskan oleh faktor-faktor lain yang tidak diteliti dalam penelitian ini.

Analisis statistik inferensial yang digunakan untuk menguji hipotesis penelitian yang berbunyi " superviisi akademik guru Madrasah Aliyah mempunyai pengaruh yang signifikan terhadap kinerja guru Madrasah Aliyah di Kabupaten Barru". Untuk menguji hipotesis penelitian dilakukan anlisis regresi. Data yang digunakan yaitu skor variabel supervisi akademik (X2), dan skor kinerja guru (Y). Analisis regresi dilakukan dengan memakai X sebagai variabel bebas dan Y sebagai varibel tak bebas. 
Analisis regresi linear sederhana dengan uji-F dengan taraf signifikan 0,05 maka hasil statiatik uji-F (nilai $\mathrm{p}=0,000$ ) menunjukkan $\mathrm{H} 0$ ditolak atau $\mathrm{H} 1$ diterima. Ini berarti bahwa varibel X2 mempunyai pengaruh yang signifikan dengan variabel tak bebas $\mathrm{Y}$.

Besarnya sumbangan variabel supervisi akademik terhadap kinerja guru madrasah Aliyah di Kabupaten Barru ditunjukkan oleh koefisien determinasi (r2) sebesar 0,891 atau 89,1, persen. Artinya, variansi perubahan variabel kinerja guru Madrasah Aliyah dapat dijelaskan oleh variabel supervvisi akademik sebesar 89,1 persen, sedang 10,9 persen lainnya dapat dijelaskan oleh faktor-faktor lain yang tidak diteliti dalam penelitian ini.

Analisis statistik inferensial yang digunakan untuk menguji hipotesis penelitian yang berbunyi "Diklat fungsional guru mempunyai pengaruh yang signifikan terhdap kinerja guru Madrasah Aliyah di Kabupaten Barru". Untuk menguji hipotesis penelitian dilakukan analisis regresi. Data yang digunakan yaitu skor varibel diklat fungsional (X.3), dan skor kinerja guru Madrasah Aliyah (Y). Analisis regresi dilakukan dengan memakai X sebagai variabel bebas dan Y sebagai varibel tak bebas.

Analisis regresi linear sederhana dengan uji-F dengan taraf signifikan 0,05 maka hasil statiatik uji-F (nilai $\mathrm{p}=0,000$ ) menunjukkan $\mathrm{H} 0$ ditolak atau $\mathrm{H} 1$ diterima. Ini berarti bahwa varibel $\mathrm{X}$ mempunyai pengaruh yang signifikan dengan variabel tak bebas $\mathrm{Y}$.

Besarnya sumbangan varibel diklat guru terhadap kinerja guru Madrasah Aliyah ditunjukkan oleh koefisien determinasi (r2) sebesar 0,724 atau 72,4 persen. Artinya, variansi perubahan variabel kinerja guru di Kabupaten Barru dapat dijelaskan oleh variabel diklat fungsional guru sebesar 72,4 persen, sedang 27,4 persen lainnya dapat dijelaskan oleh faktorfaktor lain yang tidak diteliti dalam penelitian ini.

Analisis statistik inferensial yang digunakan untuk menguji hipotesis penelitian yang berbunyi "Kepemimpinan kepala magrasah, Supervisi akademik dan Diklat fungsional guru mempunyai pengruh yang signifikan terhadap kinerja guru Madrasah Aliyah di Kabupaten Barru". Untuk menguji hipotesis penelitin ini dilakukan analisis regresi berganda. Data yang digunakan yaitu skor varibel Kepemimpinan kepala Madrasah Aliyah, (X1), supervisi akademik (X2), dan diklat fungsional (X.3), dan skor kinerja guru Madrasah Aliyah (Y). Analisis regresi bergandar dilakukan dengan memakai X1, X2, dan X3 sebagai variabel bebas dan Y sebagai varibel tak bebas.

Analisis regresi linear sederhana dengan uji-F dengan taraf signifikan 0,05 maka hasil statiatik uji-F (nilai $\mathrm{p}=0,000$ ) menunjukkan $\mathrm{H} 0$ ditolak atau $\mathrm{H} 1$ diterima. Ini berarti bahwa varibel $\mathrm{X} 1, \mathrm{X} .2$ dan ,X3 secara bersama- sama mempunyai pengaruh yang signifikan dengan variabel tak bebas $\mathrm{Y}$.

Besarnya sumbangan varibel diklat fungsional terhadap kinerja guru Madrasah Aliyah di Kabupaten Barru ditunjukkan oleh koefisien determinasi (r2) sebesar 0,976 atau 97,6 persen. Artinya, variansi perubahan variabel kinerja guru Madrasah Aliyah dapat dijelaskan oleh variabel secara bersama- sama kepemimpinan kepala Madrasah Aliyah, supervisi dan diklat fungsional sebesar 97,6 persen, sedang 2,4 persen lainnya dapat dijelaskan oleh faktor-faktor lain yang tidak diteliti dalam penelitian ini. 


\section{Simpulan dan Saran}

Berdasarkan hasil analisis desrkriptif dan hasil analisis inferensial serta pembahasan hasil penelitian pada bab sebelumnya dapat dikemukakan beberapa kesimpulan dan saran sebagai berikut:

1. Kepemimpinan kepala Madrasah, Supervisi Akademik, Diklat Fungsional Guru secara simultan berpengaruh positif dan signifikan terhadap kinerja guru pada Madrasah Aliyah di Kabupaten Barru sebesar 97,6 persen dan 2,4 persen lainnya dapat dijelaskan oleh faktor-faktor lain yang tidak diteliti dalam penelitian ini

2. Kepemimpinan kepala Madrasah berpengaruh secara positif dan signifikan terhadap Kinerja Guru pada Madrasah Aliyah di Kabupaten Barru sebesar 96,9 persen, dan 3,1 persen lainnya dapat dijelaskan oleh faktor-faktor lain yang tidak diteliti dalam penelitian ini,

3. Supervisi Akademik mempunyai pengaruh positif dan signifikan terhadap Kinerja Guru Madrasah Aliyah di Kabupaten Barru sebesar 89,1 persen, sedang 10,9 persen lainnya dapat dijelaskan oleh faktor-faktor lain yang tidak diteliti dalam penelitian ini.

4. Diklat fungsional mempunyai pengaruh positif dan signifikan terhadap Kinerja Guru Madrasah Aliyah di Kabupaten Barru. sebesar 72,4 persen, dan 26,6 persen lainnya dapat dijelaskan oleh faktor-faktor lain yang tidak diteliti dalam penelitian ini.

Berdasarkan kesimpulan penelitian yang telah dikemukakan di atas dapat diajukan beberapa saran sebagai berikut:

1. Pengambilan sumpah kepala madrsah sebagai pemimpin organisasi perlu dipertegas. Hal ini dimaksudkan agar kepala madrasah mampu melaksanakan fungsi dan perannya sebagai pemimpin madrasah

2. Pemerintah perlu memperlakukan permendikbud nomor 28 tahun 2010 tentang masa jabatan kepala sekolah/ madrasah sekama 4 tahun,

3. Mekanisme jabatan kepala sekolah / madrasah wajib memiliki nomor urut kepala sekolah / madrasah,

4. Lembaga-lembaga yang terkait dengan pelaksanaan diklat fungsional guru, perlu dilaksanakan secara kontinyu sesuai bidang ilmunya dan sesuai dengan kepentingan guru sebagai tenaga pendidik dan tenaga pengajar.

5. Pelaksanaan supervisi akademik perlu dilaksanakan secara berkesinambungan.

6. Kepada para guru raji mengikuti diklat yang diadakan oleh lembaga-lembaga terkait dengan diklat fungsional yang berhubungan dengan tingkat kompetensi profesional guru madrasah

7. Kepada para peneliti selanjutnya agar dapat mengkaji lebih dalam tentang kaitan antara kepemimpinan, supervisi akademik dan diklat fungsional guru dengan peningkatan kinerja guru madrasah aliyah, karena penelitian ini baru bersifat penjenjangan belum terlaksana secara mendalam.

\section{DAFTAR PUSTAKA}

Arikunto, 2001. Organisisi dan Adminstrasi Pendidikan, Jakarta: Rajawali Prees

Alemu, Daniel S. 2016. Dysfunctional Organization: The Leadership Factor; Open Journal of Leadership,(Online), ( http://www.scirp.-org/journal/ojl, diakses 10 Januari 2021). 
Depdikbud. 2001. Buku Tiga Pengelolaan Ketenagaan. Jakarta : Direktorat Jenderal Dikdasmen.

Depdiknas. 2003. Sistem Pendidikan Nasional. Jakarta: Biro Hukum Organisasi.

Depdiknas. 2005. Undang- undang guru dn dosen . Bandung: PT.Cipta Umbara

Glickman, 2007. Supervision of Intruction A. Depelopmen Approch Nedhan dan Heights MA: Allyn dan Bacom

Gomes, F. Candoso.2000. Manajemen Sumber Daya Manusia. Yogyakarta: Ande Offset.

Glickman C.D 2001. Development Supervision Alternative Practice for Helping Teacher Improve Intruction. Virginia, Alexandria: ASCD

Hamalik, Oemar. 2001. Proses Belajar Mengajar. Jakarta : Bumi Aksara.

Hasibuan, Malayu SP. 2005. Manajemen Sumber Daya Manusia. Edisi Revisi. Jakarta: Bumi Aksra.

Husnan. 2006. Manajemen Personalian. Yogyakarta: BPEE.

Imron, Ali. 1995. Pembinaan Guru di Indonesia. Jakarta: Pustaka Jaya.

Joni, T.R. 1991. Kurikulum Inti Program Pendidikan Guru S1. Jakarta: LPTK.

Kantao. Djamaluddin. 2002. Guru Profesional. Palu Yayasan Masa Depan.

Kunandar.2007 Guru Profesional, Implementasi Kurikulum Tingkat Satuan Pendidikan (KTSP) dan Sukses dalam Sertifikasi Guru. Jakarta: GrafindoPersada.

Mandra, M. Saeruddin. 2005. Manajemen Pendidikan dan Diklat. Makassar: PPs.UNM. Makssar.

Peraturan Menteri Pendidikan Nasional RI. Nomor 13 Tahun 2007, Tentang Kepala Sekolah / Madrasah, Jakarta: BSNP

Rahman. 2006. Peran Strategis Kepala Sekolah Dalam Meningkatkan Mutu Pendidikan. Jatinangor: Alqaprint.

Saefullah, 2012. Manajemen Pendidikan Islam. Bandung: Pustaka Setia

Sudjana. 1999. Metode Statistik. Bandung: Transito.

Usman, M. Uzer. 2011. Menjadi Guru Profesional. Bandung: Remaja Rosdakarya. 